\title{
Axons emanating from dendrites: phylogenetic repercussions with Cajalian hues
}

\author{
Lazaros C. Triarhou* \\ Laboratory of Theoretical and Applied Neuroscience, Department of Educational Policy, University of Macedonia, Thessalonica, Greece \\ *Correspondence: triarhou@uom.gr
}

Edited by:

James A. Bourne, Monash University, Australia

Reviewed by:

Paul Manger, University of the Witwatersrand, South Africa

Alino Martinez-Marcos, Universidad de Castilla, Spain

Keywords: neuron polarity, Pedro Ramón, Santiago Ramón y Cajal, evolution, ontophylogeny

\section{INTRODUCTION}

The observation that some axons, in hippocampal pyramidal neurons, emanate from dendrites rather than the somatic envelope, and the contributory synaptic input privilege (Thome et al., 2014) was highlighted as a new dimension in understanding input-output transformations (Kaifosh and Losonczy, 2014). Applying state-of-art immunocytochemical, neurophysiological, and computational methods to Thyl-DsRed transgenic, wild-type C57BL/6J mice, and Wistar rats, Thome et al. (2014) found that one-half of CA1, one-third of CA3, and one-fifth of subicular pyramidal cells feature axoncarrying dendrites (ACDs).

Two-photon glutamate uncaging onto ACD spines led to excitatory postsynaptic potentials (EPSPs) and output action potentials (APs) at lower activation $\Delta$-thresholds compared to nonACDs (Thome et al., 2014). EPSPs arising at nonACDs pass the soma and attenuate before reaching the axon initial segment (AIS), whereas in ACDs the electrotonic distance between excitatory synapses and the AP trigger zone is shorter. ACDs have a higher propensity to generate active dendritic d-spikes, primarily mediated by voltage-gated $\mathrm{Na}^{+}$channels, and consistent with a lower functional density of A-type $\mathrm{K}^{+}$channels (Kaifosh and Losonczy, 2014).

A question outstanding is to what extent this dendrito-axonal particularity is evolutionarily regulated across species (Kaifosh and Losonczy, 2014). I weave data from comparative studies to illuminate its phylogenetic basis.

\section{MAMMALS TO INSECTS}

Axons occasionally emanate from dendrites in neocortical pyramidal cells (Peters et al., 1968; Sloper and Powell, 1979), midbrain dopamine neurons (Häusser et al., 1995), GABA interneurons targeting CA1 pyramidal dendrites (Martina et al., 2000), and neuroendocrine cells (Herde et al., 2013).

Generalities regarding mechanisms are greater at lower than higher levels; to decipher connections leading to motor patterns, neurons and networks are analyzed in molluscs, crustaceans, lampreys, worms, amphibians, and arthropods (Burrows, 1992). Intracellular recordings from insect motoneurons reinforce and enlarge on synaptic integration principles from the mammalian spinal cord (Simmons and Young, 2010).

In the flight motoneurons of the locust, which control the forewing or hindleg muscles, the dendritic arbor and the axon are combined into one process, attached to the soma by a slender stalk. The soma is not in the signal flow pathway. While axonal spikes are $100 \mathrm{mV}$ in amplitude and $<1 \mathrm{~ms}$ in duration, somatic signals conduct passively ( $10 \mathrm{mV}$ lasting several $\mathrm{ms}$ ). Dendrites with voltage-sensitive channels in their membrane can boost the amplitude of input signals. Thus, when an electrode is inserted into the motoneuron dendritic fan, near the axon origin rather than the soma, EPSPs rise and fall more sharply (Burrows, 1992; Gabbiani et al., 2002; Simmons and Young, 2010).

\section{RAMÓN AND CAJAL}

Axons arising from dendrites in vertebrates and invertebrates were documented by Santiago Ramón y Cajal and his younger brother Pedro Ramón. In 1897 Cajal realized that "contrary to the general opinion, the soma does not always participate in the conduction of received nerve impulses; the afferent wave is sometimes propagated directly from dendrites to axon" (Ramón y Cajal, 1937). Accordingly, Cajal substituted his principle of dynamic polarization with axopetal polarization, whereby soma and dendrites conduct the waves of the nervous excitation toward the axon, which in turn carries impulses toward its terminal arborizations. "Currents flowing into the axon do not pass through the soma except when the latter is between the dendritic and the axonal apparatus" (Ramón y Cajal, 1897, 1937). Given the integrative processes of neuronal dynamics, one gathers that, when the axon fires ahead of the soma, it must emerge from a dendrite (Häusser et al., 1995; Yuste and Tank, 1996).

Dendrite-derived axons occur in unipolar neurons of invertebrate abdominal ganglia (Ramón y Cajal, 1899, chapter $\mathrm{V}$, "Physiological inductions of neuron morphology, and connections"). The segment that connects the dendritic stem to the initial part of the axon was called accessory process by Retzius (Figure 1). Dendrite-derived axons were documented by Ramón and by Cajal in the corpúsculos del cayado ("crosier" or "shepherd's crook" cells), and in elongated fusiform cells of the optic lobe of birds, reptiles, amphibians, and fish (Ramón, 1890, 1891, 


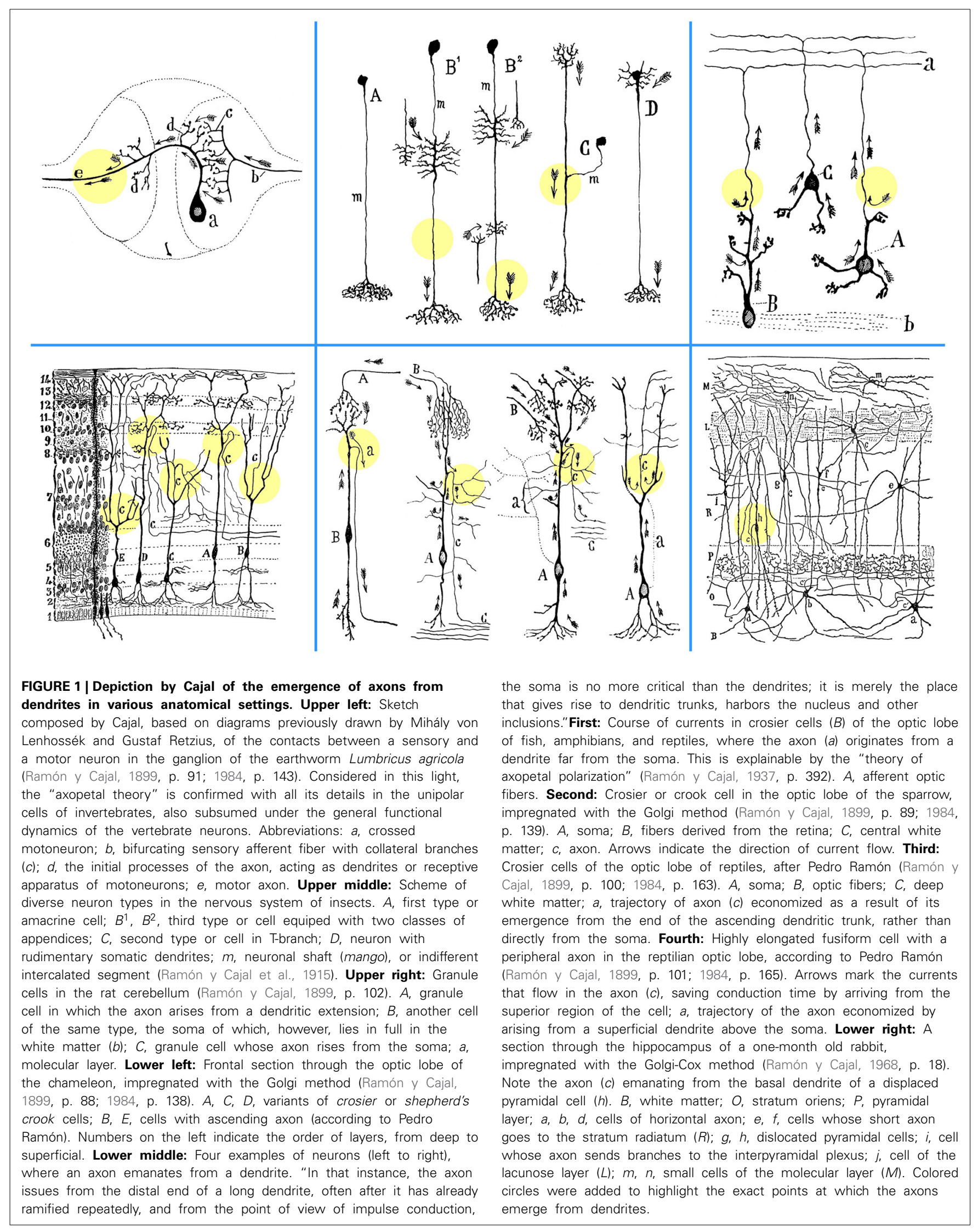


1896; Ramón y Cajal, 1891; Triarhou and del Cerro, 2008).

Dendritic axons are seen in retinal Dogiel cells, cerebellar granule cells, cortical Martinotti cells, and spinal motoneurons. In pyramidal cells of the murine, cavine, and leporine hippocampus Ramón y Cajal (1968) noted that the axon sometimes arises from the soma and at other times from a thick protoplasmic process. Van der Loos (1976) found that onetenth of cortical pyramidal cells in rabbits become improperly oriented ("inverted") during migration, their axons emanating from either the soma or apical dendrites, an arrangement not observed in properlyoriented cells.

Sensory neurons in vertebrate spinal ganglia are unipolar, with the axon and the axopetal process (that serves as dendrite) originating from a common somatic stem. In the spinal ganglia of amphibians, reptiles, birds, and mammals, sensory neurons undergo a transient phase of bipolarity, and subsequently metamorphose into unipolar; thus, the soma ceases to lie between the two types of processes, and, in dynamic terms, "it is now removed from the direct pathway between skin and spinal cord." In some fish, spinal ganglia neurons retain their bipolarity in maturity (Ramón y Cajal, 1984).

The surmise of a privileged synaptic input channel in ACDs (Thome et al., 2014) resonates Ramón y Cajal's (1899, 1984) laws of economy of conduction time, of saving cellular material and of economy of space to explain the emission of axons from dendrites or the unipolar form of spinal ganglion cells in worms, molluscs, crustacea, and insects.

The ontophylogenetic metamorphosis of sensory neurons from bipolar to unipolar and the concomitant transformation of a primordial winding path into rectilinear yield reduced distances, and shorter times for impulses to travel and information to be transferred; according to Cajal, "such a unipolar form was attained in stages, be it by natural selection or other evolutionary forces." This idea is in harmony with the finding that the atypical cadherin Fat3 ensures in retinal amacrine cell precurors a transition from bipolar to unipolar, as they migrate through the neuroblastic layer (Deans et al., 2011).
The extrasomatic origin of axons from dendritic trunks reflects a conservation of cytoplasm, i.e., avoiding "senseless" waste of tissue matter: "Impulses gathered by distal dendritic branches have no reason whatsoever to pass through the soma; instead, they flow directly to the axon" (Ramón y Cajal, 1899).

\section{CYTOSKELETAL PROMPTS}

After axotomy of reticulospinal neurons in lampreys (Petromyzon marinus), sprouts with axon-like properties emanate from dendrites (Hall et al., 1989). Dendritederived axons ("dendraxons") were reported after axotomy in $\alpha$-motoneurons of cat spinal cord (level L7) (Lindå et al., 1985). Novel "dendrite-derived supernumerary axons" can be functional, as suggested by voltage-gated $\mathrm{Na}^{+}$channel distribution and synaptophysin and glycoprotein SV2 expression, molecular prerequisites for AP propagation and neurotransmitter release (Meehan et al., 2011). Axotomized spinal commissural interneurons (level C3) also form de novo axon-like processes from distal or proximal dendrites or from the original axonal pole (Fenrich et al., 2007).

In dissociated and organotypic cultures of mouse hippocampus, proximally axotomized neurons yield new axons, with dynamic growth cones, from the tip of preexisting basal or apical dendrites; in distal axotomies, axons regrow from their central stump. Axons growing from dendrites of severed CA1 pyramidal neurons ex vivo can establish functional synapses (GomisRüth, 2007). In short, neurons retain a plasticity of polarity in development and maturity.

Axonal identity in developing and mature neurons is specified by microtubules; their stabilization with taxol, which decreases the catastrophe rate, induces multiple axon formation from differentiated dendrites (Gomis-Rüth et al., 2008). Microtubule stabilization triggers a positive feedback loop that includes changes in actin dynamics and axonal transport, complementary regulators of neuronal polarization. Signaling cascade molecules that control microtubule stability, such as glycogen synthase kinase3 (GSK3) and collapsin response mediator protein-2 (CRMP2), play an active role in axonal determination and regrowth
(Sweet and Firestein, 2008). Extracellular cues orchestrate the intracellular signaling that leads to axon-dendrite polarization in development (Barnes and Polleux, 2009). GSK3 $\beta$ is a critical regulator of polarity; GSK3 $\beta$ inhibition or depolymerization of the actin cytoskeleton converts immature dendrites into axons.

\section{SPONGY ORIGINS}

Neuronal networks are shaped by natural selection (Simmons and Young, 2010). Neurons are thought to have originated early in the evolution of eumetazoans, some 700,000,000 years ago, after diverging from sponges; the latter, a more ancient phyletic lineage, lack true neurons, a cnidarian-bilaterian synapomorphy (Richards et al., 2008). Nonetheless, the sponge Amphimedon queenslandica developmentally expresses, in migrating "globular" subepithelial cells destined to populate the larval epithelium, the proneural basic helix loop helix (bHLH) gene AmqbHLH1, coupled with Notch-Delta signaling, in a manner that resembles conserved molecular mechanisms of primary bilaterian neurogenesis. AmqbHLH1 later duplicated to produce the atonal/neurogenin-related bHLH gene families, with strong proneural activity in Xenopus and Drosophila (Ma et al., 1996; Kim et al., 1997). Thus, eumetazoan neural differentiation and the bilaterian neurogenic circuit were probably added to an already established cell-determination program operational in the metazoan stem lineage, generating an ancient sensory cell type.

Amphimedon's globular cells express components of what became the eumetazoan postsynapse, demonstrating that potential precursor components of neurons might be available in an ancestor which preceded true neurons. Globular cells have protruding apices receptive to environmental stimuli and a vesiclepacked cytosol (Richards et al., 2008). Therefore, early metazoans already possessed proto-neural cells, whose function plausibly entailed a primeval output (molecular secretion) in response to a sensory input (environmental stimuli).

\section{SYNTHESIS}

Ramón y Cajal (1995) postulated that the appearance of impulse polarity during 
animal evolution coincided with that of the nervous system itself, simply a consequence of tissue differentiation into sensory (skin and sense organs), and motor surfaces (glands and muscles).

Neurons common to all nervous systems must have evolved from an ancestral proto-cell, the properties of which remain a subject of speculation. Presentday neurons were necessarily predated by more rudimentary forms, intermediate in the genesis of their elaborate genetic, metabolic, and structural systems. A common ancestor of all neurons may not have differed much from some presentday sponge cells, its host organism having dwelled in an aquatic environment.

In today's neurons, information generally flows from dendrites to axons. In early evolution, however, a unipolar form (sensing) could have practically predated the bipolar form (sensory-motor). Arguments include: (1) sensory protoneural cells had secretion as a primitive form of output, while motor output as an axonal function arrived later; (2) neuroendocrine and paracrine secretion systems are phylogenetically older than synaptic neurotransmitter systems; (3) dendrites may occasionally subserve input and output neuronal functions, by both receiving synaptic input and concomitantly releasing neurotransmitter (e.g., nigral dendrites). The advent of dendrites represents a watershed in neuron morphology and function.

Compared with crucial dendritic and somatic functions (commonalities include cytoplasmic organelles, enzymes, and biophysical properties), those fulfilled by the later elaborated axon and AIS are most intricate. This does not mean that dendrites could replace axons; but the compelling suggestion is that dendrites preceded axons in archaic neuron evolution and temporarily served, with the soma, a combined receptor-effector role.

One might suppose that, in phylogeny, ontogeny, and regeneration, a primitive process, strictly dendritic in form, could acquire, by progressive specification, the morphofunctional characters of the axis cylinder. In this hypothetical picture, unipolar proto-neural sponge cells gave rise to neurons. A unipolar form, with one process comprising dendrite and axon, was retained in later life forms, like insects.
Bipolar forms evolved, as in fish. In mammals, an ontogenetic de-differentiation from bipolarity to unipolarity would confer a functional advantage, as highlighted by the important recent findings for hippocampal pyramidal neurons.

\section{ENVOY}

In Cajal's words, "obstacles in research can be overcome by a rational interpretation based on established facts of ontophylogeny; if we descend in the animal scale (worms, molluscs, crustaceans), or go back to early embryonic stages, we readily realize how the neuron assumed its form in vertebrates (amphibians, reptiles, mammals)" (Ramón y Cajal, 1899). A "triple-synthesis" was also one of the prime contributions of Christofredo Jakob: "Knowledge of the structure of the nervous system is reached by the following methods: comparative anatomy-embryology, development, and experimentally-induced degenerations" (Jakob, 1896); in other words, "looking at the brain, usually after a bit of tampering, and always with some kind of a microscope" (Van der Loos, 1976).

\section{REFERENCES}

Barnes, A. P., and Polleux, F. (2009). Establishment of axon-dendrite polarity in developing neurons. Annu. Rev. Neurosci. 32, 347-381. doi: 10.1146/annurev.neuro.31.060407.125536

Burrows, M. (1992). Local circuits for the control of leg movements in an insect. Trends Neurosci. 15, 226-232. doi: 10.1016/0166-2236(92)90040-F

Deans, M. R., Krol, A., Abraira, V. E., Copley, C. O., Tucker, A. F., and Goodrich, L. V. (2011). Control of neuronal morphology by the atypical cadherin Fat3. Neuron 71, 820-832. doi: 10.1016/j.neuron.2011.06.026

Fenrich, K. K., Skelton, N., MacDermid, V. E., Meehan, C. F., Armstrong, S., Neuber-Hess, M. S., et al. (2007). Axonal regeneration and development of de novo axons from distal dendrites of adult feline commissural interneurons after a proximal axotomy. J. Comp. Neurol. 502, 1079-1097. doi: $10.1002 / \mathrm{cne} .21362$

Gabbiani, F., Krapp, H. G., Koch, C., and Laurent, G. (2002). Multiplicative computation in a visual neuron sensitive to looming. Nature 420, 320-324. doi: 10.1038/nature01190

Gomis-Rüth, S. (2007). Revealing the Plasticity of Polarization in Mature Hippocampal Neurons: Changing Dendritic to Axonal Identity (Ph.D. Dissertation). München: Ludwig-MaximiliansUniversität.

Gomis-Rüth, S., Wierenga, C. J., and Bradke, F. (2008). Plasticity of polarization: changing dendrites into axons in neurons integrated in neuronal circuits. Curr. Biol. 18, 992-1000. doi: 10.1016/j.cub.2008.06.026
Hall, G. F., Poulos, A., and Cohen, M. J. (1989). Sprouts emerging from the dendrites of axotomized lamprey central neurons have axonlike ultrastructure. J. Neurosci. 9, 588-599. Available online at: http://www.jneurosci.org/content/9/2/ 588

Häusser, M., Stuart, G., Racca, C., and Sakmann, B. (1995). Axonal initiation and active dendritic propagation of action potentials in substantia nigra neurons. Neuron 15, 637-647. doi: 10.1016/0896-6273(95)90152-3

Herde, M. K., Iremonger, K. J., Constantin, S., and Herbison, A. E. (2013). GnRH neurons elaborate a long-range projection with shared axonal and dendritic functions. J. Neurosci. 33, 12689-12697. doi: 10.1523/jneurosci.0579-13.2013

Jakob, C. (1896). An Atlas of the Normal and Pathological Nervous Systems (Transl. by J. Collins). New York, NY: William Wood.

Kaifosh, P., and Losonczy, A. (2014). The inside track: privileged neural communication through axoncarrying dendrites. Neuron 83, 1231-1234. doi: 10.1016/j.neuron.2014.09.003

Kim, P., Helms, A. W., Johnson, J. E., and Zimmerman, K. (1997). XATH-1, a vertebrate homolog of Drosophila atonal, induces a neuronal differentiation within ectodermal progenitors. Dev. Biol. 187, 1-12. doi: 10.1006/dbio. 1997.8572

Lindå, H., Risling, M., and Cullheim, S. (1985). "Dendraxons" in regenerating motoneurons in the cat: do dendrites generate new axons after central axotomy? Brain Res. 358, 329-333. doi 10.1016/0006-8993(85)90978-3

Ma, Q., Kintner, C., and Anderson, D. J. (1996). Identification of neurogenin, a vertebrate neuronal determination gene. Cell 87, 43-52. doi: 10.1016/S0092-8674(00)81321-5

Martina, M., Vida, I., and Jonas, P. (2000). Distal initiation and active propagation of action potentials in interneuron dendrites. Science 287, 295-300. doi: 10.1126/science.287.5451.295

Meehan, C. F., MacDermid, V. E., Montague, S. J., Neuber-Hess, M., and Rose, P. K. (2011). Dendrite-derived supernumerary axons on adult axotomized motor neurons possess proteins that are essential for the initiation and propagation of action potentials and synaptic vesicle release. J. Neurosci. 31, 6732-6740. doi 10.1523/jneurosci.5377-10.2011

Peters, A., Proskauer, C. C., and Kaiserman-Abramof, I. R. (1968). The small pyramidal neuron of the rat cerebral cortex: the axon hillock and initial segment. J. Cell Biol. 39, 604-619. doi: 10.1083/jcb.39.3.604

Ramón, P. (1890). Investigaciones de Histología Comparada en los Centros Ópticos de Distintos Vertebrados (Tesis del Doctorado, Facultad de Medicina de la Universidad Central de Zaragoza). Madrid: Imprenta Colonial.

Ramón, P. (1891). El encéfalo de los reptiles. Trab. Lab. Histol. Fac. Med. (Zaragoza) 1891, 1-33.

Ramón, P. (1896). Estructura del encéfalo del camaleón. Rev. Trimest. Micrográf. (Madrid) 1, 131-167.

Ramón y Cajal, S. (1891). Sur la fine structure du lobe optique des oiseaux et sur l'origine réelle des nerfs optiques. Int. Mschr. Anat. Physiol. (Leipz.) 8, 337-366. 
Ramón y Cajal, S. (1897). Leyes de la morfología y el dinamismo de las células nerviosas. Rev. Trimest. Micrográf. (Madrid) 2, 1-28.

Ramón y Cajal, S. (1899). Textura del Sistema Nervioso del Hombre y de los Vertebrados, tomo I. Madrid: Nicolás Moya [Facsimile edition 1992 by C. Belmonte, J. Merchán, and S. Ramón y Cajal Junquera. Alicante: Instituto de Neurociencias and Gráficas Vidal Leuka].

Ramón y Cajal, S. (1937). Recollections of My Life (Transl. by E. Horne Craigie and J. Cano). Philadelphia: American Philosophical Society.

Ramón y Cajal, S. (1968). The Structure of Ammon's Horn (Transl. by L. M. Kraft). Springfield, IL: Charles C. Thomas.

Ramón y Cajal, S. (1984). The Neuron and the Glial Cell (Transl. by J. de la Torre and W. C. Gibson). Springfield, IL: Charles C. Thomas.

Ramón y Cajal, S. (1995). Histology of the Nervous System (Transl. by N. Swanson and L. W. Swanson). New York, NY: Oxford University Press.

Ramón y Cajal, S., and Sánchez, D. (1915). Contribución al conocimiento de los centros nerviosos de los insectos. Trab. Lab. Invest. Biol. Univ. Madrid 13, 1-164.

Richards, G. S., Simionato, E., Perron, M., Adamska, M., Vervoort, M., and Degnan, B. M. (2008). Sponge genes provide new insight into the evolutionary origin of the neurogenic circuit.
Curr. Biol. 18, 1156-1161. doi: 10.1016/j.cub.2008. 06.074

Simmons, P. J., and Young, D. (2010). Nerve Cells and Animal Behaviour, 3rd Edn. Cambridge: Cambridge University Press. doi: 10.1017/CBO9780511782138

Sloper, J. J., and Powell, T. P. S. (1979). A study of the axon initial segment and proximal axon of neurons in the primate motor and somatic sensory cortices. Philos. Trans. R. Soc. Lond. Biol. Sci. 285, 173-197. doi: 10.1098/rstb.1979.0004

Sweet, E. S., and Firestein, B. L. (2008). Neuronal polarization: old cells can learn new tricks. Curr. Biol. 18, R661-R663. doi: 10.1016/j.cub.2008.06.057

Thome, C., Kelly, T., Yanez, A., Schultz, C., Engelhardt, M., Cambridge, S. B., et al. (2014). Axon-carrying dendrites convey privileged synaptic input in hippocampal neurons. Neuron 83, 1418-1430. doi: 10.1016/j.neuron.2014.08.013

Triarhou, L. C., and del Cerro, M. (2008). Pedro Ramón (Cajal's brother) and his pivotal contributions to evolutionary neuroscience. Schweiz. Arch. Neurol. Psychiatry 159, 419-428. Available online at: http://www.sanp.ch/ docs/2008/2008-07/2008-07-039.pdf

Van der Loos, H. (1976). Neuronal circuitry and its development. Prog. Brain Res. 45, 259-278. doi: 10.1016/S0079-6123(08)60994-2
Yuste, R., and Tank, D. W. (1996). Dendritic integration in mammalian neurons, a century after Cajal. Neuron 16, 701-716. doi: 10.1016/S08966273(00)80091-4

Conflict of Interest Statement: The author declares that the research was conducted in the absence of any commercial or financial relationships that could be construed as a potential conflict of interest.

Received: 14 October 2014; paper pending published: 28 October 2014; accepted: 30 October 2014; published online: 18 November 2014.

Citation: Triarhou LC (2014) Axons emanating from dendrites: phylogenetic repercussions with Cajalian hues. Front. Neuroanat. 8:133. doi: 10.3389/fnana. 2014.00133

This article was submitted to the journal Frontiers in Neuroanatomy.

Copyright (c) 2014 Triarhou. This is an open-access article distributed under the terms of the Creative Commons Attribution License (CC BY). The use, distribution or reproduction in other forums is permitted, provided the original author(s) or licensor are credited and that the original publication in this journal is cited, in accordance with accepted academic practice. No use, distribution or reproduction is permitted which does not comply with these terms. 